\title{
Zašto je snižen kreditni rejting Zagrebačkom holdingu?
}

\author{
dr. sc. Anto Bajo
}

\section{Uvod}

U petak 22. studenog 2008. godine Kreditna agencija Moody's snizila je rejting Zagrebačkom komunalnom holdingu (u nastavku Holding) s Baa2 na Baa3 (dobar rejting sa srednje na nižu kategoriju sposobnosti plaćanja) te Gradu Zagrebu s Baa1 na Baa2 (dobar rejting s više na srednju kategoriju dobre sposobnosti plaćanja). Rejting im je snižen zbog visokog zaduženja Holdinga i slabih uvjeta za otplatu duga, te uglavnom odražava pogoršanje financijske pozicije Holdinga. Unatoč niskom izravnom dugu Grada, njegova izloženost financijskom poslovanju Holdinga znatna je i u porastu je. Gradu Zagrebu posljedično je smanjen rejting jer Holding treba subvencije i jamstva gradskog proračuna. Holding je u posljednje dvije godine pokrenuo velike kapitalne investicije zbog kojih se njegov dug iz 2006. godine gotovo utrostručio. Sniženje rejtinga Grada i Holdinga rezultat je visokog zaduženja Holdinga, koji se izravno odrazio i na financijsku i kreditnu poziciju Grada. Stoga se otvara pitanje kvalitete i financijskog poslovanja komunalnih društava u Holdingu, posebice utjecaja zaduživanja i dugova Holdinga na zaduživanje gradskog proračuna. ${ }^{1}$

\section{Gradski proračun i proračun Holdinga - spojene ili razdvojene posude}

Holding čine 22 trgovačka društva u 100-postotnom vlasništvu Grada Zagreba koja posluju prema Zakonu o trgovačkim društvima i obveznici su poreza na dobit i na dodanu vrijednost. Holding se najvećim dijelom financira namjenskim prihodima (više od 50\%), zbog čega bi mogao imati status izvanproračunskog korisnika (fonda) Grada Zagreba. Tada bi financijski plan (proračun) Holdinga mogao ući i u formalnu proceduru odobravanja od Skupštine Grada, kao i gradski proračun.

Gradski proračun i proračun Holdinga formalno ne funkcioniraju prema načelu spojenih posuda. Gradsko poglavarstvo predlaže, a skupština Grada usvaja proračun, ali ne i financijske planove Holdinga. Najveći dio financijskih kapitalnih transakcija Grad obavlja putem proračuna Holdinga, koji odobrava Nadzorni odbor i daje ga na uvid Skupštini Holdinga (jedini je član Skupštine gradonačelnik kao predstavnik Gradskog vijeća). Predstavnici Holdinga jedanput u godini podnose Gradskom poglavarstvu izvješće o poslovanju za prošlu godinu, a Gradsko poglavarstvo izvješće Holdinga razmatra i upućuje

\footnotetext{
${ }^{1} \mathrm{U}$ analizi su korišteni podaci iz izvješća o prihodima i rashodima Grada Zagreba od 2002. do 2007. (dostupno na http://www.mfin.hr), te financijski izvještaji Zagrebačkog holdinga, d.o.o., zajedno s izvještajem neovisnog revizora od 31. prosinca 2007 (dostupno na http://www.zagrebackiholding.com/Default.aspx?tabid=281).
} 
Gradskoj skupštini. Dakle, financijski plan i izvješće o financijskom poslovanju (proračunu) Holdinga ne prolazi isti stupanj formalnosti (pripreme, odobrenja, izvršenja i revizije) kao proračun Grada. ${ }^{2}$ Zbog toga ne postoji objedinjeni (ukupni) konsolidirani proračun koji bi uz proračun Grada činio i proračun (izvješće o financijskom poslovanju) Holdinga te omogućio uvid u veličinu i strukturu imovine, ukupnog duga i ukupne financijske pozicije Grada (gradskog i proračuna Holdinga).

Za dobivanje cjelovite slike imovine, financijskog poslovanja Grada, a posebice veličine dugova nastalih putem Holdinga, potrebno je konsolidirati financijska izvješća Holdinga i Grada. To formalno ne bi trebao biti problem jer je Holding u vlasništvu Grada. Međutim, zbog statusa Holdinga kao trgovačkog društva to za sada nije moguće.

Grad s Holdingom financijski posluje na načelu spojenih posuda jer se sredstva iz gradskog proračuna prelijevaju u obliku subvencije, ali i davanjem jamstava na zaduženja Holdingu. Napomenimo da su subvencije Holdingu iz gradskog proračuna narasle s 477 mil. kuna u 2002. na 670 mil. kuna u 2007. godini. Od 2002. do 2007. godine iz gradskog je proračuna za subvencije Holdingu izdvojeno 3,4 mlrd. kuna i izdano 1,4 mlrd. kuna jamstava.

\section{Dug i zaduživanje Gradskog proračuna}

Izravni je dug proračuna nizak i Grad se pridržava Vladinih proračunskih ograničenja na zaduživanja. Međutim, glavnina zaduživanja ostvaruje se putem Holdinga, kojim se Grad koristi za zaobilaženje Vladinih proračunskih ograničenja. Od 2002. do 2007. smanjeni su zajmovi Grada vlastitim trgovačkim društvima, kao i primici od zaduživanja. Međutim, ostaje pitanje je li to rezultat povoljne financijske pozicije Grada ili je riječ o prebacivanju zaduživanja iz gradskog proračuna u Holding. Za dobivanje cjelovitog odgovora potrebno je odvojeno analizirati financijsku poziciju grada i financijsku poziciju Holdinga, a posebice detaljnije utvrditi uvjete i strukturu zaduživanja Holdinga u 2006. i 2007. godini.

\section{Financijska pozicija Gradskog proračuna}

Financijska pozicija Grada, mjerena kao neto financijska imovina odnosno kao razlika između likvidne financijske imovine (novca u banci, depozita, danih zajmova, vrijednosnih papira) i (kreditnih) obveza, zadovoljavajuća je. Grad nema većih problema s likvidnošću. Postojeće obveze gradskog proračuna u cijelosti su pokrivene raspoloživom gotovinom na računu u poslovnoj banci.

Tablica 1. Financijska pozicija i likvidnost proračuna Grada Zagreba od 2005. do 2007. (u mil. kn), stanje na kraju razdoblja

\begin{tabular}{|l|l|r|r|r|}
\hline & & 2005. & 2006. & 2007. \\
\hline 1. & Financijska imovina & 820 & 539 & 593 \\
\hline & Novac u banci i blagajni & 628 & 374 & 481 \\
\hline & Depoziti, jamčevni polozi i potraživanja & 85 & 65 & 60 \\
\hline & Zajmovi (dani) & 63 & 61 & 20 \\
\hline & Vrijednosni papiri & 45 & 39 & 32 \\
\hline $\mathbf{2 .}$ & Obveze za zajmove & 481 & 349 & 350 \\
\hline $\mathbf{1}$-2) & Neto financijska imovina & 339 & 191 & 242 \\
\hline
\end{tabular}

Izvor: Financijska izvješća Grada Zagreba, 2008.

\footnotetext{
2 Reviziju financijskog poslovanja Holdinga u 2007. obavila je privatna revizorska tvrtka. Reviziju gradskog proračuna obavlja Državni ured za reviziju.
} 
Neto financijska pozicija Grada je pozitivna te Gradu nakon pokrića obveza za kredite i dalje ostaje oko 240 mil. kuna likvidne financijske imovine. Financijski problemi mogu nastati zbog danih jamstava na zaduživanje Holdinga, koja se mogu aktivirati zbog njegova nepovoljnoga financijskog položaja. U 2007. dana jamstva Grada za zaduživanje Holdinga iznosila su 1,4 mlrd. kuna, od čega je novih 200 mil. kuna izdano upravo te godine.

Ukupne izravne (kreditne) obveze grada iznose 350 mil. kuna. Međutim, Grad je odobrio jamstva u vrijednosti 1,4 mlrd. kuna, zbog čega je ukupni (izravni i potencijalni) dug proračuna 1,75 mlrd. kuna. Zahvaljujući izdanim jamstvima, financijska pozicija može biti narušena ako Holding ne bi bio u stanju vraćati kamate i glavnicu duga.

Tablica 2. Neto financijska pozicija Grada (u mil. kn), stanje na kraju razdoblja

\begin{tabular}{|l|l|c|c|c|}
\hline & & $\mathbf{2 0 0 5 .}$ & $\mathbf{2 0 0 6 .}$ & $\mathbf{2 0 0 7 .}$ \\
\hline $\mathbf{1 .}$ & Financijska imovina & 820 & 539 & 593 \\
\hline $\mathbf{2 .}$ & $\begin{array}{l}\text { Izravne i potencijalne financijske } \\
\text { obveze }\end{array}$ & 481 & 349 & 1.713 \\
\hline & Obveze za zajmove & 481 & 349 & 350 \\
\hline & Stanje aktivnih jamstava & 0 & 0 & 1.363 \\
\hline $\mathbf{( 1 - 2 )}$ & Neto financijska pozicija & $\mathbf{3 3 9}$ & $\mathbf{1 9 1}$ & $\mathbf{- 1 . 1 2 1}$ \\
\hline
\end{tabular}

Izvor: autorov izračun na temelju podataka iz financijskih izvješća Grada Zagreba

Uz pesimističan scenarij Gradu bi ostao dug oko 1,1 mlrd. kuna. Stoga se pozornost treba pridati kvaliteti poslovanja Holdinga i njegovoj održivosti kako ne bi postao izravna prijetnja financiranju osnovnih gradskih funkcija.

\section{Financijska pozicija Holdinga - je li Holding prijetnja gradskom proračunu?}

Izvor potencijalne financijske nestabilnosti gradskih financija treba tražiti u financijskom poslovanju Holdinga. Prihodi Holdinga porasli su s 3,3 mlrd. u 2006. na 4,3 mlrd. kuna u 2007. godini. Međutim, nije jasno je li to realni rast ili rezultat proširenja obuhvata i kvalitetnije konsolidacije svih prihoda trgovačkih društava u sastavu Holdinga. Rashodi su manji od prihoda te je proračun Holdinga prije oporezivanja ostvarivao viškove (dobit) koji su se s 88 mil. kuna u 2006. smanjili na 30 mil. kuna 2007. godine.

Tablica 3. Proračun Holdinga ( $u$ mil. kn)

\begin{tabular}{|l|r|r|}
\hline & $\mathbf{2 0 0 6 .}$ & $\mathbf{2 0 0 7 .}$ \\
\hline Prihodi poslovanja & 3.252 & 4.150 \\
\hline Financijski prihodi & 89 & 156 \\
\hline Ukupni prihodi & 3.341 & 4.306 \\
\hline Rashodi poslovanja & 3.132 & 4.044 \\
\hline Financijski rashodi & 121 & 231 \\
\hline Ukupni rashodi & 3.253 & 4.276 \\
\hline Višak/manjak & 88 & 30 \\
\hline
\end{tabular}

Izvor: Financijsko izvješće Holdinga, 2008.

Na prvi pogled čini se da je riječ o stabilnom financijskom poslovanju, međutim, Holding se u dvije godine znatnije zaduživao kod banaka, ali i na međunarodnome financijskom tržištu. Ukupan je dug Holdinga porastao s 1,4 mlrd. kuna u 2006. na 4 mlrd. kuna u 2007. godini. Znatniji rast duga u 2007. godini rezultat je izdavanja 2 mlrd. kuna obveznica na Londonskoj burzi. Stoga pogledajmo okvirne pokazatelje zaduživanja Holdinga u 2006. i 2007. 
Tablica 4. Pokazatelji zaduženosti Holding ( $u$ mlrd. kn)

\begin{tabular}{|l|c|c|}
\hline \multicolumn{1}{|l|}{} & $\mathbf{2 0 0 6 .}$ & $\mathbf{2 0 0 7 .}$ \\
\hline Ukupni prihodi & 3,3 & 4,3 \\
\hline Kapital i rezerve & 6,9 & 6,9 \\
\hline Temeljni kapital & 4,3 & 4,2 \\
\hline Ukupni dug & 1,4 & 4,0 \\
\hline \multicolumn{2}{|l|}{} \\
\hline ukg kao postotak & 43 & 93 \\
\hline kapitala i rezervi & 21 & 59 \\
\hline temeljnog kapitala & 33 & 95 \\
\hline
\end{tabular}

Izvor: Financijsko izvješće Holdinga, 2008.

Dug Holdinga u 2007. čini 93\% prihoda i 95\% temeljnog kapitala društva (Grad Zagreb u Holdingu ima 4,2 mlrd. kuna vlasničkog udjela). S obzirom na ročnost, $91 \%$ duga je s dugim rokom dospijeća (oko 10 godina), a 9\% su kratkoročne obveze (do jedne godine). U 2007. $55 \%$ duga bilo je u vlasništvu inozemnih, a $45 \%$ u vlasništvu domaćih vjerovnika. Riječ je uglavnom o dugoročnim obvezama koje dospijevaju do 2017. godine. Većina je kreditnih obveza (94\%) Holdinga u eurima.

U nastavku je dana struktura glavnih dužnika u sklopu Holdinga.

Tablica 5. Glavni dužnici u sklopu Holdinga (u mil. kn), stanje na kraju razdoblja

\begin{tabular}{|l|r|r|r|r|}
\hline & \multicolumn{2}{|c|}{$\begin{array}{c}\text { Iznos duga } \\
\text { (u mil. kn) }\end{array}$} & \multicolumn{2}{c|}{$\begin{array}{c}\text { Postotak } \\
(\%)\end{array}$} \\
\hline & $\mathbf{2 0 0 6 .}$ & $\mathbf{2 0 0 7 .}$ & $\mathbf{2 0 0 6 .}$ & $\mathbf{2 0 0 7 .}$ \\
\hline Zagrebački električni tramvaj & 858 & 1.005 & 60 & 25 \\
\hline Vodoopskrba i odvodnja & 293 & 277 & 21 & 7 \\
\hline Sljeme, Medvednica & 32 & 28 & 2 & 1 \\
\hline Robni terminali Zagreb & 84 & 259 & 6 & 6 \\
\hline Zagreb parking & 27 & 124 & 2 & 3 \\
\hline ZGOS - skupljanje i odvoz smeća & 127 & 90 & 9 & 2 \\
\hline Zagrebačke ceste & 9 & 2 & 1 & 0 \\
\hline Čistoća & 0 & 35 & 0 & 1 \\
\hline Obveznice, EURO & 0 & 2,198 & 0 & 55 \\
\hline Ukupno & 1.430 & 4.018 & 100 & 100 \\
\hline
\end{tabular}

Izvor: Financijsko izvješće Holdinga, 2008.

Pojedinačno su najveći dužnici u sklopu Holdinga ZET, s 1 mlrd. kuna, te Vodoopskrba i odvodnja, s 277 mil. kuna.

\section{Uvjeti zaduživanja, ročnost, kamatne stope, osiguranja povrata kredita}

Holding se u promatranom razdoblju zaduživao kod domaćih poslovnih banaka uz nepovoljne uvjete. Prosječne kamatne stope bile su oko $7 \%$, s tim da se Holding kod HBOR-a zadužio po kamatnoj stopi od 7,2\%, a kod pojedinih domaćih poslovnih banaka po stopi većoj i od $9 \%{ }^{3}$ Pojedini su krediti Holdinga osim fiksne kamate vezani za tromjesečni libor i euribor.

\footnotetext{
3 Prema podacima HNB-a, prosječne ponderirane kamatne stope na dugoročne kredite $s$ valutnom klauzulom za trgovačka društva bile su u 2006. godini 5,77\%, a u 2007. godini 6,15\%. Kamatne stope za kredite u eurima bile su 5,34\% u 2006. godini i 5,65\% u 2007. godini (dostupno na http://www.hnb.hr/statistika/hstatistika.htm).
} 
Osim toga, za otplatu kredita Holding dodatno jamči svojom imovinom (založnim pravima na pokretnine i nekretnine) te izdaje zadužnice, mjenice, akceptne naloge kao lako unovčive instrumente. Za dio dugova Holdinga Grad je dodatno izdavao jamstva.

Pokazuje se da je jedno od najpovoljnijih zaduženja Holdinga izdavanje obveznica na Londonskoj burzi u iznosu od 300 mil. eura, s kamatnom stopom od 5,6\%, koja se otplaćuje godišnje. Prema tom zaduživanju, Holdingu nisu potrebna dodatna jamstava poput onih kojima je koristio pri zaduživanju kod domaćih financijskih institucija.

\section{Osvrt Državnog ureda reviziju na izdana jamstva Grada}

Stanje danih jamstava na koncu 2006. iznosi 1.695.301.115 kn. Trgovačkom društvu s područja gradskog prijevoza dano je jamstvo u 2002. u iznosu 840.5 mil. kn uz sukcesivno korištenje kredita do konca 2006. (do konca 2006. kredit je iskorišten u iznosu 640 mil. kn ili 76\%). Od 2002. do konca 2006. otplata glavnice kredita nije bilo. Iz obrazloženja, koje je dano za zaključak Gradske skupštine, proizlazi da nije riječ o davanju jamstva, već o zaduživanju Grada, jer sredstva za povrat kredita trgovačkog društva treba osigurati u gradskom proračunu od 2002. do 2006. Od 2004. do 2006., trgovačkim društvima, obavljen je prijenos sredstava za otplate kredita po danim jamstvima u iznosu 146.5 mil. kn, a nisu ih iskazali u otplatama kredita po danim jamstvima i danim suglasnostima. (http://www.revizija.hr)

\section{Financijska pozicija Holdinga}

Usporedbom raspoložive financijske imovine i financijskih obveza dolazi se do okvirne financijske pozicije Holdinga u 2006. i 2007. godini - neto financijska pozicija Holdinga pogoršala se.

Tablica 6. Neto financijska pozicija Holdinga ( $u$ mil. kn), stanje na kraju razdoblja

\begin{tabular}{|l|r|r|}
\hline & $\mathbf{2 0 0 6 .}$ & $\mathbf{2 0 0 7 .}$ \\
\hline Vrijednosni papiri & 2 & 1 \\
\hline Dani krediti, depoziti ${ }^{4}$, kaucije & 160 & 0 \\
\hline Ostala kratkoročna ulaganja & 0 & 0 \\
\hline Novac u blagajni, na žiro-računu i u banci & 154 & 435 \\
\hline 1. Ukupna financijska imovina & 315 & 435 \\
\hline Krediti & 1.430 & 1.821 \\
\hline Obveznice & 0 & 2.198 \\
\hline 2. Ukupne financijske obveze & 1.430 & 4.019 \\
\hline 3. Neto financijska imovina (1-2) & -1.115 & -3.583 \\
\hline
\end{tabular}

Izvor: Financijsko izvješće Holdinga, 2008.

U 2006. Holding je imao manjak financijske imovine od 1,1 mlrd. kuna, a 2007. od čak 3,6 mlrd. kuna. Razlog je novo zaduživanje za financiranje kapitalnih projekata poput zagrebačke arene, ali možda čak i za financiranje tekućih izdataka. Zbog nastalih obveza stupanj likvidnosti Holdinga je nizak.

\footnotetext{
${ }^{4}$ Zbog jednokratnog učinka na rast financijske imovine u depozite nisu uključeni primici od zaduživanja koje je Holding oročio u poslovnim bankama (vidjeti na http://www.zagrebackiholding.com/Default.aspx?tabid=281 bilješke uz financijske izvještaje društva, str. 43) do aktiviranja plaćanja obveza za financiranje kapitalnih projekata u 2008. i 2009. godini.
} 


\section{Zaključak}

Na temelju analize financijskog poslovanja može se reći da će buduće financiranje Grada uvelike ovisiti o stabilnosti financiranja Holdinga. Cijene komunalnih usluga mogle bi rasti, kao i subvencije Grada za financiranja otplate duga jer obveze Holdinga prema domaćim i inozemnim vjerovnicima čine oko 95\% njegova temeljnog kapitala. Općenito, nije jasno zbog čega se Holding prije nije zaduživao izdavanjem obveznica nego uz nepovoljne uvjete kod domaćih financijskih institucija. Za privatna poduzeća nije neobično da su obveze čak i veće od njihova temeljnog kapitala. Međutim, za društva u vlasništvu lokalnih jedinica (pa i države), koje imaju monopol u pružanju javnih usluga, teret otplate kreiranih obveza često se izravno prenosi na građane putem viših cijena usluga. 